\title{
Business Impact Analysis of supply chain disruptions
}

\author{
G. Wieteska \\ Department of Logistics, Faculty of Management, University of Lodz
}

\begin{abstract}
This paper is devoted to the issue of business continuity management. Today, in a turbulent global environment, companies are exposed to an increasing number of internal and external uncertainties. These adverse events disturb processes and bring negative consequences. In the context of anticipating, responding to and restoring from the crisis situations, it is vital to perform a supply chain business impact analysis. The conducted research was designed twofold. First, a Systematic Literature Review on Business Impact Analysis was conducted. Here, the desk research method was used. Here, the desk research method was used. It revealed, that the supply chain BIA is a very rare subject of research. During the second stage, a CATI survey was performed among 202 of the largest manufacturing companies operating in Poland. The results supported the answering of seven research questions that concerned two main BIA parameters, which are 'disruption impact' and 'disruption time'. The study analysed the most serious disturbances of eleven supply chain processes. Many interesting conclusions have been formulated. The highest negative triple bottom line (TBL) impact of supply chain disruptions regard the financial losses. The disruptions affect the time performance indicators the most. A process that is vulnerable to the largest TBL consequences is 'supply logistics', whereas 'purchasing and supplier relationship management' suffers from the longest interruptions. BIA needs to include various consequences including the reputational one.
\end{abstract}

Keywords: Business Impact Analysis, continuity management, supply chain processes, disruption, KPI

\section{Introduction}

In today's turbulent business environment, organizations need to be prepared for the worst scenarios by building resilient supply chains that are based both on proactive and reactive strategies (Hohenstein et al. 2015, Tukamuhabwa et al. 2015). In order to deal with disturbances and maintain the required service level during crisis situations, it is essential that companies develop an array of abilities, including the abilities to respond and to recover (Ali, Mahfouz and Arisha 2017). The starting point for the preparation of continuity and recovery plans is a business impact analysis (BIA). BIA is the main method of the supply chain continuity management concept, which has been developing ever since the terrorist attack on the World Trade Center in 2001 (Zsidisin, Melnyk and Ragatz 2005, Benyoucef and Forzley 2007, The Business Continuity Institute 2008a p.7, ISO/DTS 22317:2015).

The main aim of this paper is to exam the characteristics of the most serious supply chain disruptions using BIA parameters - which are disruption impact and disruption time.

The article consists of several sections: theoretical (on the definition of BIA), the methodology, and a discussion on the research results and conclusions. A two-phase methodology, based on both a qualitative and quantitative method survey, was used. In the first part of the research, the desk research method was applied and a literature review was conducted. In the second part of the research, a survey was performed.

\section{Business Impact Analysis definition - a standards' approach}

The international system management standard related to the business continuity management is ISO 22301:2014, whereas ISO/DTS 22317:2015 is an international technical specification that directly relates to Business Impact Analysis. It recommends managing the BIA process according to the 
Deming Cycle. Furthermore, it provides 'guidance for planning, conducting, and reporting on BIA' In the introduction, it is explained that BIA is 'a process for analysing the consequences of a disruptive incident on the organization'. According to The Business Continuity Institute (2008b, p.4) BIA is 'a process for evaluating the impact over time of a disruption to an organisation's ability to operate'. Furthermore, BIA considers sudden and rapid events causing significant business disruption (The Business Continuity Institute 2008a, p.7). This implies that BIA is a tool for recognizing the potential scenarios of crisis situations in relation to the criticality of the performed processes.

A disruption is 'an event, whether anticipated (e.g. a labour strike or hurricane) or unanticipated (e.g. a blackout or earthquake), which causes an unplanned, negative deviation from the expected delivery of products or services according to the organisation's objectives' (ISO/DTS 22318:2015, p. 3). When a disruptive does incident occur, losses can grow dramatically depending on the timeframe. That is why analysis of the consequences of disruptions should be analysed through the two following parameters: disruption impact (consequences/losses) and disruption time. The time unit can be expressed by in minutes, hours or days, it all depends on the business's specificity, as this will determine the speed of the appearance of losses. With regard to the consequences, ISO/DTS 22317:2015 lists the following examples of disruption impact categories: financial, reputational, legal and regulatory, contractual and business objectives. During BIA, it is important to identify processes, activities and resources whose disruptions lead to the most serious consequences the most rapidly (Table 1$)$.

Table 1. The example of BIA of manufacturing process disruption.

\begin{tabular}{|c|c|c|c|c|c|}
\hline Disruption time & $\mathbf{1}$ day & $\mathbf{3 ~ d a y s}$ & $\mathbf{5}$ days & $\mathbf{7}$ days & $\mathbf{1 4}$ days \\
\hline $\begin{array}{c}\text { Manufacturing } \\
\text { process }\end{array}$ & $\mathbf{1}$ & $\mathbf{3}$ & $\mathbf{3}$ & $\mathbf{4}$ & $\mathbf{5}$ \\
\hline Function A & 1 & 3 & 3 & 4 & $\mathbf{5}$ \\
\hline Function B & 1 & 1 & 1 & 2 & 3 \\
\hline Function C & 1 & 2 & 2 & 3 & 4 \\
\hline Process/function & \multicolumn{6}{|c|}{ Expected consequences of a particular disruption. The assessment used a } \\
\end{tabular}

Source: own elaboration

The manufacturing process and its three functions $(\mathrm{A}, \mathrm{B}, \mathrm{C})$ were analysed for several time periods in terms of their disruption consequences. The critical function here is Function A, whose disruption leads to the most serious consequences in the shortest timeframe. This means that this process need to be resumed with the greatest priority. The key BCM time measure is Recovery Time Objective (RTO), which is 'a target time following an incident for: product or service delivery resumption, or activity resumption, or resources recovery' (ISO/DTS 22317:2015, p. 19). BIA provides information about critical business activities and enhances the prioritization of the processes performed. Finally, it determines the continuity strategy options, as it is one of the elements of the business continuity management concept (Figure 1). Figure 1. The elements of BCM.

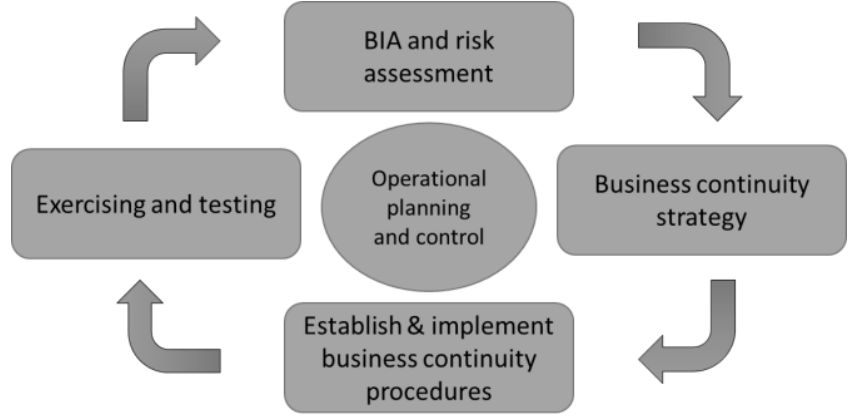

Source: ISO/DTS 22318:2015 
In the international standards on business continuity, the issue of supply chain management is also present. ISO/DTS 22318:2015 is devoted to the Supply Chain Continuity Management (SCCM). It recommends mapping and analysing the supply chain in terms of the external and internal risks. Additionally, it suggests segmenting suppliers according to their criticality. Subsequently, it encourages decision making on continuity strategy options, among which the standard distinguishes: reducing dependency, increasing the resilience of the company, increasing resilience of suppliers or even exiting from cooperation with a partner (ISO/DTS 22318:2015, p.14).

\section{Methodology}

\subsection{Systematic literature review}

The first part of the research, based on desk research, used a literature review methodology, applied following Tranfield, Denyer and Smart (2003). The review process consisted of the following phases: question formulation, keyword search in databases, screening (closer inspection, removing duplicates, checking cited articles) and analysis of articles. First, the main research question - what is the current state of research on supply chain BIA? - was constructed. In the second phase, the author used the leading providers of research databases, which are EBSCOhost Online Research Databases, Emerald Insight, Scopus, Web of Science and Wiley Online Library. Two search terms and the following restrictions were used in the phase of the databases search:

- Search term 1: ' business impact analysis' AND

- Search term 2: 'supply chain', restriction: occurrence in abstract (Scopus and Web of Science imposed 'title, abstract and keywords' field to be searched).

To ensure the highest quality of the systematic literature review (SLR), the research covered such sources as journals and books. There was no restriction on the date of publication, in order to identify as many publications as possible. However, a surprisingly small number of items were found in the individual databases (Table 2). In light of this, the author decided to perform the second search using only one search term: 'business impact analysis' and the restriction: occurrence in abstract. This allowed the identification of more papers and chapters, although these concerned various domains.

Table 2. Results of database research

\begin{tabular}{|c|c|c|c|c|c|}
\hline Database & Search 1 & $\begin{array}{l}\text { Additional } \\
\text { restrictions }\end{array}$ & $\begin{array}{c}\text { Output } \\
\text { (number of } \\
\text { papers) } \\
\end{array}$ & Search 2 & $\begin{array}{r}\begin{array}{r}\text { Output } \\
\text { (number } \\
\text { of papers) }\end{array} \\
\end{array}$ \\
\hline EBSCOhost & \multirow{5}{*}{$\begin{array}{c}\text { Search } \\
\text { terms: } \\
\text { 'business } \\
\text { impact } \\
\text { analysis' } \\
\text { AND } \\
\text { 'supply chain' }\end{array}$} & $\begin{array}{l}\text { journals, academic } \\
\text { journals, eBooks }\end{array}$ & 2 & \multirow{5}{*}{$\begin{array}{l}\text { Search } \\
\text { term: } \\
\text { 'business } \\
\text { impact } \\
\text { analysis' }\end{array}$} & 23 \\
\hline Emerald & & - & 0 & & 0 \\
\hline Scopus & & $\begin{array}{l}\text { document type: } \\
\text { articles, books, book } \\
\text { chapters }\end{array}$ & 5 & & 42 \\
\hline Web of Science & & $\begin{array}{l}\text { articles, book } \\
\text { chapters }\end{array}$ & 0 & & 15 \\
\hline $\begin{array}{l}\text { Wiley Online } \\
\text { Library }\end{array}$ & & journals, books & 0 & & 12 \\
\hline
\end{tabular}

Source: own elaboration

Detailed results of the desk research are presented in the fourth section of the article. 


\subsection{Survey}

The quantitative phase of the research used the Computer Assisted Telephone Interview (CATI) method, which was chosen to ensure data availability. In the author's experience, in the last ten years, the return percentage of paper questionnaires in postal surveys has drastically decreased in Poland. The selection of the sample in the study was deliberate. The researched enterprises were large manufacturing companies (employing 250 or more employees) from various industries, conducting production activity in Poland.

The sampling used the "Rzeczpospolita" newspaper database "500 List" and was also supported by the Bisnode database. The study was preceded by a pilot on the $n=3$ sample, aimed at checking the adequacy of the research tool and the quality of the collected data. The questions were designed with the proviso that they needed to be straightforward and easy to answer. After the pilot test, the final instrument was developed, with the number of researched companies reaching 202.

Large manufacturing companies from the "500 List" were chosen to ensure assessment of the approaches to supply chain management and access to best practices from the most mature companies, with interviews with respondents being carried out from October to December 2016. To ensure the reliability of the answers, the respondents chosen were senior management with key competences in the field of supply chain management and knowledge of risk management. Additionally, the following restrictions were used:

- A minimum three years' experience in the management of the supply chain in the current place of employment and

- In the last three years the occurrence of some disruptions of the business process in the company of the respondent.

First, the respondents were expected to point out one process from the last three years that had been disrupted in the most serious way and, later in the survey, to refer to its specific disruption (Table 3). According to the respondents, the production process was the most seriously disrupted process (31.19\%), followed by the logistics of production (13.86\%). The researched processes are the eleven processes developed from the framework described in the Global Supply Chain Forum model (Lambert and Cooper 2000).

Table 3 . The most seriously disrupted supply chain processes in the last three years. Percentage of indications [\%].

\begin{tabular}{|l|l|}
\hline The most seriously disrupted process in the last 3 years* & {$[\%]$} \\
\hline Development and commercialization of products (DEVCOM) & 8.42 \\
\hline Purchasing and supplier relationship management (PURSRM) & 7.92 \\
\hline Supply logistics (SUPLOG) & 6.93 \\
\hline Production (PROD) & $\mathbf{3 1 . 1 9}$ \\
\hline Logistics of production (LOGPROD) & 13.86 \\
\hline Demand management (DEM) & 10.89 \\
\hline Implementation of business clients' orders, including distribution logistics in the B2B market (IMPLB2B) & 5.45 \\
\hline Implementation of business clients' orders, including distribution logistics in the B2C market (IMPLB2C) & 2.48 \\
\hline Customer service management (CUSTSER) & 5.45 \\
\hline Customer relationship management (CRM) & 2.97 \\
\hline Return management and reverse logistics (RETREV) & 4.46 \\
\hline None & 0.00 \\
\hline
\end{tabular}

Source: Wieteska (2018).

The questionnaire was divided into three parts:

A. The first part was related to the types of supply chain processes that were disrupted in the most serious way and the way the disturbances spread out in the supply chain. It also covered the cause of the disturbance. The results of this part are presented in another paper (Wieteska 2018).

B. The second part was related to the impact of process disruptions in terms of time and impact. 
C. The third part was related to the type of implemented supply chain adaptive response for similar disruptions that might occur in the future and to the maturity of their approach to the supply chain risk and business continuity management.

This paper refers to part B of the questionnaire. It mainly answers the following research questions:

1. What is the triple bottom line (TBL): financial, environmental, and social impact of disruptions of supply chain processes? (Likert scale, 1 - none, 2 - very low, 6 - very high).

2. What is the impact of disruptions of supply chain processes on the reputation of companies? (Likert scale, 0 - none, 1 - very low, 5 - very high).

3. What KPIs are deteriorated due to the disruptions of supply chain processes? Possible answers (yes/no): quality, time, costs, flexibility (Bozarth and Handfield 2012, p. 22) 4. What is the impact of disruptions on the objectives of supply chain processes? (Likert scale 0 - none, 1 very low, 5 - very high).

5. What is the size of the consequences of process disruptions for the supply chain? (Likert scale, 0 - none, 1 - very short, 5 - very long)?

6. What is the average length of the interruption in supply chain processes (expressed in days)?

7. What was the company's response time to the disruptions? (Likert scale, 1 - very short, 5 very long).

Each research question was related to a survey question. These are introduced in the fifth section. The data are presented in the form of tables and using various characteristics: average $(\mathrm{M})$, median $(\mathrm{Me})$, standard deviation $(\sigma)$, maximum (Max) and minimum (Min) value.

\section{Business Impact Analysis in the literature}

The detailed results of the desk research enabled the recognition of several findings on the current state of research on BIA. In 'Search 1' (Table 2), after removing duplicates, it was found that only six papers relate to the supply chain BIA issue. This provides an important conclusion - that there is a significant literature gap in this regard. The next paragraphs in this section briefly present the recognized articles.

Blos, Wee and Yang (2010) elaborated the supply chain continuity framework, which includes the stages of business continuity planning (one of which is business impact analysis) and various operational constructs (e.g. time to market, ordering cycle time, flexibility). Hegedus and PeevaMúller (2014) highlighted the necessity of managing IT risks in modern supply chains with the use of business continuity planning methodologies, including BIA. Montshiwa and Nagahira (2015) found that "risk-conscious companies reported better business impact analysis and supply chain cooperation status than did non-risk conscious companies". One year later, Montshiwa (2016) proposed a conceptual BCM model adapted from ISO 22301:2012 and confirmed, among others, the positive impact of BIA on supply chain cooperation, competitive advantage and recovery time. Montshiwa, Nagahira and Ishida (2016), in the continuation of this study, also revealed that BIA 'is the single most important part of BCP as it had the strongest positive total effects on other BCP factors'. For their quantitative research, the authors used a survey method. In the last, and most recent, investigated paper on BIA in the supply chain, Park, Hyun and Kim (2016) proposed a resource allocation model for recovery plans, intended to reduce any negative consequences of natural disasters.

'Search 2' (Table 1) highlighted that many papers on the BIA issue are published in the area of computer science (e.g. Salmela 2008, Radeschütz, Schwarz and Niedermann 2015). Some of these cover information management systems (Yang, Ku and Liu 2016). In addition, the growing trend of articles on BIA in medicine (e.g. Suginaka et al. 2014) and health services (e.g. Roberts and Molyneux 2010) are noticeable. The publications covering the BIA method often refer to business continuity management standards (Tammineedi 2010, Montshiwa 2016). Finally, the papers on BIA 
$8^{\text {th }}$ International Conference on Management, Economics and

Humanities

7 - 9 December, $2018 \quad$ Barcelona, Spain

are usually published in journals in the disaster management field, like the 'Journal of Business Continuity \& Emergency Planning' or the 'Journal of Disaster Research'. Summarizing, most papers research BIA as one of several areas/stages of the BCM concept. Articles concentrating exclusively on the BIA issue are still scarce. This paper attempts to fill this gap.

\section{Discussion on survey results}

The gathered data are presented in Table 4, which shows the evidence that supports research questions1-7 and presents detailed information on the characteristics of particular supply chain process disruptions. These characteristics refer directly to disruption impact (consequences/losses) and disruption time, which are the main BIA parameters.

Table 4. The impact of disruptions on supply chain processes.

\begin{tabular}{|c|c|c|c|c|c|c|c|c|c|c|c|c|c|}
\hline & & & The & nost s & eriou & y dis & uptec & supply & ain proc & in the $\mathrm{l}$ & 3 years & & \\
\hline & $\begin{array}{l}\text { Process } \\
\text { disruption } \\
\text { characterist } \\
\text { i } \\
\text { cs }\end{array}$ & $\begin{array}{l}\overline{8} \\
\text { है } \\
\text { 令 }\end{array}$ & $\sum_{\substack{0 \\
0 \\
⿱ 亠 䒑 ⿱ ⺊ 口}}$ & 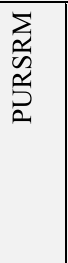 & $\begin{array}{l}0 \\
0 \\
\text { 号 } \\
\text { क }\end{array}$ & $\begin{array}{l}0 \\
a \\
a\end{array}$ & $\begin{array}{l}0 \\
0 \\
0 \\
0 \\
0\end{array}$ & 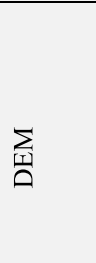 & $\sum_{\substack{n \\
ٍ}}^{\infty}$ & 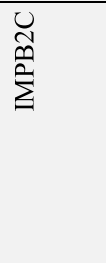 & $\begin{array}{l}\frac{\alpha}{\omega T} \\
\frac{1}{\omega} \\
\omega \\
己 \\
己\end{array}$ & $\sum^{2}$ & 䒚 \\
\hline \multirow{20}{*}{\begin{tabular}{l|}
0 \\
0 \\
0 \\
0 \\
$\overline{0}$ \\
0 \\
0 \\
0 \\
0 \\
0 \\
0 \\
0 \\
0 \\
0
\end{tabular}} & \multirow{5}{*}{$\begin{array}{l}\text { Financial } \\
{[1-6]}\end{array}$} & $\mathrm{M}$ & 3.47 & 3.69 & 3.86 & 3.33 & 3.25 & 3.50 & 3.45 & 3.20 & 2.36 & 3.00 & 2.78 \\
\hline & & $\mathrm{Me}$ & 3.00 & 3.50 & 4.00 & 3.00 & 3.00 & 3.00 & 3.00 & 3.00 & 2.00 & 2.50 & 3.00 \\
\hline & & $\sigma$ & 0.85 & 1.40 & 1.06 & 1.14 & 1.02 & 1.34 & 1.30 & 1.47 & 0.98 & 1.63 & 0.79 \\
\hline & & $\begin{array}{l}\mathrm{Ma} \\
\mathrm{x}\end{array}$ & 5.00 & 6.00 & 6.00 & 6.00 & 6.00 & 6.00 & 6.00 & 6.00 & 5.00 & 6.00 & 4.00 \\
\hline & & Min & 2.00 & 2.00 & 2.00 & 2.00 & 2.00 & 2.00 & 2.00 & 2.00 & 1.00 & 1.00 & 2.00 \\
\hline & \multirow{5}{*}{$\begin{array}{c}\text { Environ } \\
\mathrm{m} \\
\text { ental } \\
{[1-6]}\end{array}$} & $\mathrm{M}$ & 1.88 & 1.25 & 1.71 & 1.30 & 1.32 & 1.32 & 1.45 & 1.00 & 1.18 & 1.00 & 1.22 \\
\hline & & $\mathrm{Me}$ & 1.00 & 1.00 & 1.00 & 1.00 & 1.00 & 1.00 & 1.00 & 1.00 & 1.00 & 1.00 & 1.00 \\
\hline & & $\sigma$ & 1.13 & 0.56 & 1.10 & 0.90 & 0.71 & 0.76 & 1.44 & 0.00 & 0.39 & 0.00 & 0.42 \\
\hline & & $\begin{array}{l}\mathrm{Ma} \\
\mathrm{x}\end{array}$ & 4.00 & 3.00 & 4.00 & 6.00 & 4.00 & 4.00 & 6.00 & 1.00 & 2.00 & 1.00 & 2.00 \\
\hline & & Min & 1.00 & 1.00 & 1.00 & 1.00 & 1.00 & 1.00 & 1.00 & 1.00 & 1.00 & 1.00 & 1.00 \\
\hline & \multirow{5}{*}{$\begin{array}{l}\text { Social } \\
{[1-6]}\end{array}$} & M & 1.29 & 1.50 & 1.79 & 1.30 & 1.46 & 1.45 & 1.00 & 1.00 & 1.09 & 1.50 & 1.56 \\
\hline & & $\mathrm{Me}$ & 1.00 & 1.00 & 1.00 & 1.00 & 1.00 & 1.00 & 1.00 & 1.00 & 1.00 & 1.00 & 1.00 \\
\hline & & $\sigma$ & 0.75 & 1.06 & 1.15 & 0.88 & 0.98 & 0.94 & 0.00 & 0.00 & 0.29 & 1.12 & 0.83 \\
\hline & & $\begin{array}{l}\mathrm{Ma} \\
\mathrm{x}\end{array}$ & 4.00 & 4.00 & 4.00 & 5.00 & 4.00 & 4.00 & 1.00 & 1.00 & 2.00 & 4.00 & 3.00 \\
\hline & & Min & 1.00 & 1.00 & 1.00 & 1.00 & 1.00 & 1.00 & 1.00 & 1.00 & 1.00 & 1.00 & 1.00 \\
\hline & \multirow{5}{*}{$\begin{array}{l}\text { Reputatio } \\
\text { nal } \\
\quad[1-6]\end{array}$} & $\mathrm{M}$ & 1.71 & 1.63 & 2.64 & 2.03 & 2.21 & 1.77 & 2.73 & 1.80 & 1.27 & 1.67 & 1.89 \\
\hline & & $\mathrm{Me}$ & 1.00 & 1.00 & 2.00 & 2.00 & 2.00 & 1.00 & 3.00 & 1.00 & 1.00 & 2.00 & 2.00 \\
\hline & & $\sigma$ & 1.02 & 0.99 & 1.49 & 1.37 & 1.29 & 1.59 & 1.66 & 1.17 & 0.45 & 0.47 & 0.74 \\
\hline & & $\begin{array}{l}\mathrm{Ma} \\
\mathrm{x}\end{array}$ & 4.00 & 4.00 & 6.00 & 6.00 & 5.00 & 6.00 & 6.00 & 4.00 & 2.00 & 2.00 & 3.00 \\
\hline & & Min & 1.00 & 1.00 & 1.00 & 1.00 & 1.00 & 1.00 & 1.00 & 1.00 & 1.00 & 1.00 & 1.00 \\
\hline \multirow{7}{*}{ 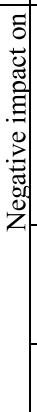 } & \multirow{5}{*}{$\begin{array}{c}\text { Achieve } \\
\text { m ent of } \\
\text { the } \\
\text { process's } \\
\text { objective } \\
{[16]}\end{array}$} & $\mathrm{M}$ & 2.82 & 3.25 & 2.57 & 2.57 & 2.93 & 3.05 & 2.00 & 2.20 & 2.36 & 2.17 & 2.44 \\
\hline & & $\mathrm{Me}$ & 3.00 & 3.00 & 2.00 & 2.00 & 3.00 & 3.00 & 2.00 & 1.00 & 2.00 & 2.00 & 2.00 \\
\hline & & $\sigma$ & 0.92 & 1.03 & 1.64 & 1.11 & 0.92 & 1.30 & 0.85 & 1.94 & 1.07 & 0.69 & 1.50 \\
\hline & & $\begin{array}{l}\mathrm{Ma} \\
\mathrm{x}\end{array}$ & 4.00 & 5.00 & 5.00 & 5.00 & 4.00 & 6.00 & 3.00 & 6.00 & 4.00 & 3.00 & 6.00 \\
\hline & & Min & 1.00 & 1.00 & 1.00 & 1.00 & 1.00 & 1.00 & 1.00 & 1.00 & 1.00 & 1.00 & 1.00 \\
\hline & $\begin{array}{r}\text { quality } \\
\text { indicators }\end{array}$ & & $\begin{array}{l}17.6 \\
5\end{array}$ & $\begin{array}{l}37.5 \\
0\end{array}$ & $\begin{array}{l}14.2 \\
9\end{array}$ & $\begin{array}{l}14.2 \\
9\end{array}$ & $\begin{array}{l}14.2 \\
9\end{array}$ & 18.18 & 0.00 & 0.00 & 0.00 & 0.00 & 0.00 \\
\hline & $\begin{array}{c}\text { time } \\
\text { indicators }\end{array}$ & {$[\%]$} & $\begin{array}{l}64.7 \\
1\end{array}$ & $\begin{array}{l}75.0 \\
0\end{array}$ & $\begin{array}{l}85.7 \\
1\end{array}$ & $\begin{array}{l}73.0 \\
2\end{array}$ & $\begin{array}{l}64.2 \\
9\end{array}$ & 63.64 & 54.55 & 80.00 & 90.91 & $\begin{array}{r}100 . \\
00\end{array}$ & 66.67 \\
\hline
\end{tabular}




\begin{tabular}{|c|c|c|c|c|c|c|c|c|c|c|c|c|}
\hline $\begin{array}{c}\text { cost } \\
\text { indicators }\end{array}$ & & $\begin{array}{l}23.5 \\
3\end{array}$ & $\begin{array}{l}37.5 \\
0\end{array}$ & $\begin{array}{l}42.8 \\
6\end{array}$ & $\begin{array}{l}38.1 \\
0\end{array}$ & $\begin{array}{l}57.1 \\
4\end{array}$ & 50.00 & 45.45 & 20.00 & 45.45 & 33.33 & 22.22 \\
\hline $\begin{array}{r}\text { flexibilit } \\
\mathrm{y} \text { indicators }\end{array}$ & & $\begin{array}{l}29.4 \\
1\end{array}$ & $\begin{array}{l}12.5 \\
0\end{array}$ & $\begin{array}{l}21.4 \\
3\end{array}$ & $\begin{array}{l}19.0 \\
5\end{array}$ & $\begin{array}{l}21.4 \\
3\end{array}$ & 27.27 & 27.27 & 40.00 & 9.09 & 0.00 & 33.33 \\
\hline \multirow{5}{*}{$\begin{array}{l}\text { Size of the } \\
\text { disruption's } \\
\text { consequences for } \\
\text { the supply chain } \\
{[1-6]}\end{array}$} & $M$ & 2.41 & 2.50 & 2.57 & 2.37 & 2.54 & 2.09 & 2.55 & 2.40 & 2.00 & 2.00 & 2.22 \\
\hline & $\mathrm{Me}$ & 2.00 & 2.00 & 2.50 & 2.00 & 2.00 & 2.00 & 2.00 & 2.00 & 2.00 & 2.00 & 2.00 \\
\hline & $\sigma$ & 0.97 & 0.94 & 1.18 & 1.12 & 1.27 & 1.12 & 0.99 & 1.36 & 1.04 & 0.58 & 0.92 \\
\hline & $\begin{array}{l}\mathrm{Ma} \\
\mathrm{x}\end{array}$ & 5.00 & 4.00 & 5.00 & 6.00 & 5.00 & 6.00 & 5.00 & 5.00 & 5.00 & 3.00 & 4.00 \\
\hline & Min & 1.00 & 1.00 & 1.00 & 1.00 & 1.00 & 1.00 & 1.00 & 1.00 & 1.00 & 1.00 & 1.00 \\
\hline \multirow{5}{*}{$\begin{array}{l}\text { Interruption } \\
\text { length } \\
\text { [day] }\end{array}$} & $\mathrm{M}$ & 3.82 & $\begin{array}{l}11.7 \\
1\end{array}$ & 8.00 & 4,55 & 5.00 & 4.25 & 5.80 & 8.75 & 6.63 & 4.20 & 12.29 \\
\hline & $\mathrm{Me}$ & 3.00 & $\begin{array}{l}11.0 \\
0\end{array}$ & 5.00 & 3.00 & 3.00 & 3.00 & 3.00 & 9.00 & 7.00 & 3.00 & 4.00 \\
\hline & $\sigma$ & 2.84 & 7.81 & 8.64 & 4.61 & 5.86 & 4.35 & 6.60 & 5.80 & 2.06 & 1.94 & 20.80 \\
\hline & $\begin{array}{l}\mathrm{Ma} \\
\mathrm{x}\end{array}$ & $\begin{array}{l}11.0 \\
0\end{array}$ & $\begin{array}{l}30.0 \\
0\end{array}$ & $\begin{array}{l}30.0 \\
0\end{array}$ & $\begin{array}{l}21.0 \\
0\end{array}$ & $\begin{array}{l}21.0 \\
0\end{array}$ & 19.00 & 25.00 & 15.00 & 10.00 & 7.00 & 63.00 \\
\hline & Min & 1.00 & 2.00 & 1.00 & 0.17 & 0.04 & 0.04 & 1.00 & 2.00 & 3.00 & 2.00 & 1.00 \\
\hline \multirow{5}{*}{$\begin{array}{l}\text { Response } \\
\text { time [1-5] }\end{array}$} & $M$ & 2.82 & $\mathbf{1 . 9 4}$ & 1.21 & 1.70 & 1.82 & 1.95 & 1.91 & 1.00 & 1.73 & 2.17 & 1.78 \\
\hline & $\mathrm{Me}$ & 3.00 & 2.00 & 1.00 & 1.00 & 2.00 & 2.00 & 1.00 & 1.00 & 2.00 & 2.50 & 2.00 \\
\hline & $\sigma$ & 0.92 & 0.97 & 0.41 & 0.83 & 0.76 & 0.98 & 1.24 & 0.00 & 0.75 & 0.90 & 0.79 \\
\hline & $\begin{array}{l}\mathrm{Ma} \\
\mathrm{x}\end{array}$ & 4.00 & 4.00 & 2.00 & 4.00 & 3.00 & 5.00 & 5.00 & 1.00 & 3.00 & 3.00 & 3.00 \\
\hline & Min & 1.00 & 1.00 & 1.00 & 1.00 & 1.00 & 1.00 & 1.00 & 1.00 & 1.00 & 1.00 & 1.00 \\
\hline
\end{tabular}

Source: own elaboration

When considering the TBL impact, the financial consequences were definitely the highest for each supply chain process disruption, whereas the level of environmental and social impact were quite similar to each other. Furthermore, the reputational impact was higher than the social one for each process disruption.

According to the results, the highest financial losses come from the disruptions of the upper supply chain and such processes as supply logistics $(M=3.86)$ and purchasing and supplier relationship management $(M=3.69)$. This confirms the trend in the literature, where papers usually show the problems with the continuity of supplies as extremely sever disruptions (Sheffi 2001, Chopra and Sodhi, 2004, Hardy 2012).

Analysing $M, M e$ and Min values, in the case of customer service management and customer relationship management the financial consequences were at the lowest level, although supply chain disruptions can result in high penalties from clients and can lead to the loss of current or even potential clients. Additional financial losses can appear when reputation is damaged (Wyman 2017, pp. 4-6). With regard to the reputational impact on all supply chain processes, the disturbances of implementation of business clients' orders, including distribution logistics in the B2B market can bring the highest losses $(M=2.73)$.

The environmental consequences brought about the most serious losses $(\mathrm{Max}=6)$ only twice: for production and implementation of business clients' orders, including distribution logistics in the $B 2 B$ market. The social consequences, however, never reached the highest level (Max=6), unlike the financial consequences and the reputational one. However, for the latter, half of the cases were of a rather low impact, as the observation of the median indicates.

The severest environmental consequences occur during development and commercialization of products $(M=1.88)$. This observation may mean that the surveyed companies are aware of the importance of "design for environment", which has a crucial role for the implementation of green production and distribution (Luttropp and Lagerstedt 2006).

It is understandable that the highest social impact is related to the supply logistics $(M=1.79)$, e.g. warehousing activities, especially due to the fact that transportation and logistics are characterized by relatively high employee turnover, both voluntary and involuntary (Mercer LCC 2017, p.14). At the same time, respondents indicated one of the highest environmental losses as the disruptions of 
supply logistics $(M=1.71)$. This may be associated, in particular, with incidents causing damage or destruction or spillages of hazardous substances.

The respondents were to indicate the most serious disruptions, which, as it transpired, hindered the objective achievement of purchasing and supplier relationship management $(M=3.25)$ and demand management $(M=3.05)$ processes the most. Additionally, in the case of only four processes (purchasing and supplier relationship management, development and commercialization of products, logistics of production, demand management), half of the disruptions reached a level higher than three $(M e=3)$. This may prove that the surveyed companies are relatively good at maintaining the appropriate process performance even during crisis situations. However, the results presenting how the disturbances affect KPIs are not so optimistic in this regard.

For the impact of supply chain disruptions on KPIs, the greatest is related to time. Time indicators were deteriorated for more than $70 \%$ of disruptions in general, whereas for the cost indicators it was nearly $40 \%$ and the flexibility indicators about $18 \%$ with the quality indicators being impacted the least (10\%) and usually in cases of disruptions of manufacturing chain processes. This confirms that the most serious disturbances bring about the most delay.

The next data show that in each case the average size of the disruption's consequences for the supply chains did not reach the third level. This partly confirms the previous conclusions that "the serious production problems of the researched companies were overcome relatively quickly. As a consequence, in most cases, they did not affect relationships with suppliers and clients" (Wieteska 2018). However, the word "quickly" was misleading when considering the next disruptions' characteristic.

Most of researched companies (80.20\%) recorded a process interruption. Analysing the interruption length, the longest were for two supply chain processes: purchasing and supplier relationship management $(\mathrm{M}=11.71, \mathrm{Max}=30)$ and return management and reverse logistics $(\mathrm{M}=12.29$, Max=63). The longest average interruption time affected production process and lasted 365 days. However, this data was removed while clearing data because of distortion reason. The shortest average interruption length concerned the process of development and commercialization of products $(\mathrm{M}=3.82)$. The product development process performed by manufacturing companies can be supported by various best practices, e.g. supplier involvement, which reduce project risk significantly (Wasti and Liker 1997). Interruption length can be interpreted as the actual recovery time. Analysing the response time, it was generally satisfactory and so RTO in many cases probably was achieved, which may place the researched companies among the risk conscious (Montshiwa and Nagahira 2015). According to the respondents, their enterprises reacted relatively quickly to the adverse events. The shortest response time was for implementation of business clients' orders, including distribution logistics in the $B 2 C$ market $(\mathrm{M}=1, \mathrm{Me}=1, \mathrm{Min}=1, \mathrm{Max}=1)$.

\section{Conclusions}

This paper raises both theoretical and managerial implications. Firstly, it provides the first systematic literature review on BIA. The SLR revealed, among others, that knowledge about BIA is described in a very limited way in academic papers. Secondly, it presents selected results of a wide study on supply chain business management. The most important conclusions being as follows:

- The highest negative TBL impact of supply chain disruptions concern the financial losses.

- The reputational losses are higher than the environmental or the social one in terms of the most serious supply chain disruptions.

- Disruptions affect the time performance indicators the most and then - in the following order - cost, flexibility and quality indicators.

- In most cases, serious supply chain disruptions cause interruptions of processes. Considering all researched disturbances, the average length of interruption of the supply chain process 
was 6 days. According to the respondents, their companies reacted relatively quickly to the adverse events.

- The BIA should address a variety of different consequences, as some effect a greater impact. Furthermore, the BIA of supply chain disruptions is the source of information on which process are disrupted, and when, bring the highest losses the fastest. The presented results can advise managers which processes, when a supply chain disruption occurs, should be restored first or support the allocation of resources (Park, Hyun and Kim, 2016). Without doubt, the critical process in terms of TBL consequences is supply logistics, whereas in terms of interruption length it is purchasing and supplier relationship management. This means that there is an urgent need for manufacturing companies to have business continuity plans in place especially for these processes.

The study is however burdened with some limitations. Firstly, the presented results concern not all data gathered in the CATI survey, which decreases the comprehensiveness of the conclusions. Secondly, it only provides descriptive statistics, whereas the considerations on the consequences of disruptions lead to the need to identify the statistical dependences between individual effects of the disturbances and verification of such hypothesis as:

H1: Greater environmental consequences of disturbances of supply chain processes are associated with greater financial consequences.

$\mathrm{H} 2$ : Greater social consequences of disturbances of supply chain processes are associated with greater financial consequences.

H3: Greater environmental consequences of disturbances of supply chain processes are associated with greater reputational consequences.

H4: Greater social consequences of disturbances of supply chain processes are associated with greater reputational consequences.

H5: Greater financial consequences of disturbances of supply chain processes are associated with greater interruption length.

Moreover, it would be interesting to understand what the characteristics of these process disruptions depend on, e.g. the source of risk (e.g. internal or external) that causes the disturbance. These and other relations will be verified in the next stage of the analysis.

\section{References}

1. Ali A., Mahfouz A., Arisha A.:' Analysing supply chain resilience: integrating the constructs in a concept mapping framework via a systematic literature review', Supply Chain Management: An International Journal, 22(1), 16-39, 2017.

2. Benyoucef M., Forzley S.:' Business continuity planning and supply chain management', Supply Chain Forum: An International Journal, 8(2), 14-22, Taylor \& Francis, 2007.

3. Blos, M. F., Wee, Hui-Ming, Yang J.: 'Analysing the external supply chain risk driver competitiveness: A risk mitigation framework and business continuity plan, Journal of Business Continuity \& Emergency Planning, 4(4), 368-374, 2010.

4. Bozarth C. B., Handfield R. B.: 'Introduction to Operations and Supply Chain Management' Pearson Prentice Hall, 3rd Edition, 2012.

5. Chopra S., Sodhi M. S.: 'Managing risk to avoid supply chain breakdown', MIT Sloan Management Review (1), 53-61, 2004.

6. Hegedus, G., Peeva-Múller, K.: 'New challenges and comprehensive risk management approaches in modern supply chains', Infocommunications Journal, 6(2), 53-56, 2014.

7. Hohenstein N.O., Feisel E., Hartmann E., Giunipero L.:'Research on the phenomenon of supply chain resilience: a systematic review and paths for further investigation', International Journal of Physical Distribution \& Logistics Management, 45(1/2), 90-117, 2015.

8. ISO/TS 22317:2015 Societal security - Business continuity management systems - Guidelines for business impact analysis (BIA), International Organization for Standardization, 2015. 
9. ISO/TS 22318:2015 Societal security - Business continuity management systems - Guidelines for supply chain continuity, International Organization for Standardization, 2015.

10. Lambert D. M., Cooper M. C.: 'Issues in Supply Chain Management', Industrial Marketing Management, 29, 65-83, 2000.

11. Luttropp C., Lagerstedt J.: 'EcoDesign and The Ten Golden Rules: generic advice for merging environmental aspects into product development', Journal of Cleaner Production, 14(15-16), 1396-1408, 2006.

12. Mercer LCC: Workforce turnover around the world', Marsh \& McLennan Companies, 2017.

13. Montshiwa, A. L., Nagahira, A.: 'Impacts of business continuity management (BCM) on automobile parts makers against natural disaster events', Journal of Disaster Research, 10(6), 1091-1098, 2015.

14. Montshiwa, A. L.: 'Optimizing diamond structured automobile supply chain network towards a robust business continuity management International', Journal of Supply \& Operations Management, 2(4), 947981, 2016.

15. Montshiwa, A. L., Nagahira, A., Ishida S.: 'Modifying business continuity plan (BCP) towards an effective auto-mobile business continuity management (BCM): A quantitative approach', Journal of Disaster Research, 11(4), 691-698, 2016.

16. Park, T., Hyun, B.-E., Kim, D.-H., 'A resource allocation problem for the business continuity plan in the supply chain network', ICIC Express Letters,10(5), 1213-1218, 2016.

17. Radeschütz S., Schwarz H., Niedermann F.: 'Business impact analysis-a framework for a comprehensive analysis and optimization of business processes', Computer Science - Research and Development, 30(1), 69-86, 2015.

18. Roberts P., Molyneux H.: 'Implementing business continuity effectively within the UK National Health Service‘, Journal of Business Continuity \& Emergency Planning, 4 (4), 352-359, 2010.

19. Salmela H.: 'Analysing business losses caused by information systems risk: A business process analysis approach', Journal of Information Technology, 23(3), 185-202, 2008.

20. Sheffi Y.: 'Supply Chain Management under the threat of International Terrorism', International Journal of Logistics Management, 12(2), 1-11, 2001.

21. Suginaka, H., Okamoto, K. Hirano, Y., Fukumoto, Y., Morikawa, M., Oode, Y., Sumi, Y., Inoue, Y., Matsuda, S., Tanaka, H.,: 'Hospital disaster response using business impact analysis', Prehospital and Disaster Medicine, 29(6), 561-568, 2014.

22. Tammineedi, R.L.: 'Business continuity management: A standards-based approach', Information Security Journal, 19(1), 36-50, 2010.

23. The Business Continuity Institute, Business Continuity Management Good Practice Guidelines. BCM policy \& programme management, 2008a.

24. The Business Continuity Institute, Business Continuity Management Good Practice Guidelines. Understanding the organisation, 2008b.

25. Tukamuhabwa B. R., Stevenson M., Busby, J., Zorzini M.:' Supply chain resilience: definition, review and theoretical foundations for further study', International Journal of Production Research, 53(18), 5592-5623, 2015.

26. Wasti S.N., Liker J. K.:'Risky business or competitive power?, Journal of Product Innovation Management, 14,(5), 337-355, 1997.

27. Wieteska G.: The domino effect - disruptions in supply chains, LogForum, 14(4), 495-506, 2018, http://dx.doi.org/10.17270/J.LOG.2018.302

28. Wyman O. Reputational Risk, Marsh \& McLennan Companies 2017

29. Zsidisin G. A., Melnyk S. A., Ragatz G. L.: 'An Institutional Theory Perspective of Business Continuity Planning for Purchasing and Supply Management', International Journal of Production Research, 43(16), 3401-3420, 2005.

30. Yang, T. H., Ku, C. Y., Liu, M. N.: 'An integrated system for information security management with the unified framework', Journal of Risk Research, 19(1), 21-41, 2016. 